\title{
Rodent models for prion diseases
}

\author{
Martin H. GROSCHUP*, Anne BUSCHMANN \\ Friedrich-Loeffler-Institut (FLI), Institute for Novel and Emerging Infectious Diseases, Südufer 10, \\ 17493 Greifswald - Insel Riems, Germany
}

(Received 2 September 2007; accepted 15 January 2008)

\begin{abstract}
Until today most prion strains can only be propagated and the infectivity content assayed by experimentally challenging conventional or transgenic animals. Robust cell culture systems are not available for any of the natural and only for a few of the experimental prion strains. Moreover, the pathogenesis of different transmissible spongiform encephalopathies (TSE) can be analysed systematically by using experimentally infected animals. While, in the beginning, animals belonging to the natural host species were used, more and more rodent model species have been established, mostly due to practical reasons. Nowadays, most of these experiments are performed using highly susceptible transgenic mouse lines expressing cellular prion proteins, PrP, from a variety of species like cattle, sheep, goat, cervidae, elk, hamster, mouse, mink, pig, and man. In addition, transgenic mice carrying specific mutations or polymorphisms have helped to understand the molecular pathomechanisms of prion diseases. Transgenic mouse models have been utilised to investigate the physiological role of $\operatorname{PrP}^{\mathrm{C}}$, molecular aspects of species barrier effects, the cell specificity of the prion propagation, the role of the PrP glycosylation, the mechanisms of the prion spread, the neuropathological roles of $\mathrm{PrP}^{\mathrm{C}}$ and of its abnormal isoform $\mathrm{PrP}^{\mathrm{D}}$ (D for disease) as well as the function of PrP Doppel. Transgenic mouse models have also been used for mapping of PrP regions involved in or required for the PrP conversion and prion replication as well as for modelling of familial forms of human prion diseases.
\end{abstract}

prion / scrapie / BSE / transgenic mouse

Table of contents

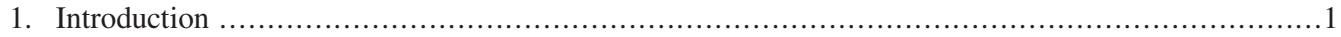

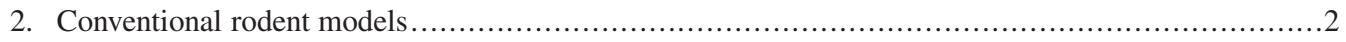

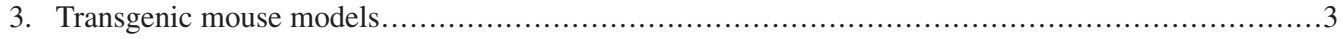

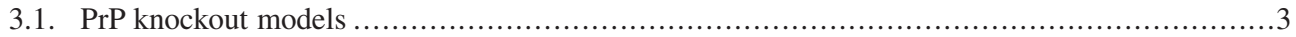

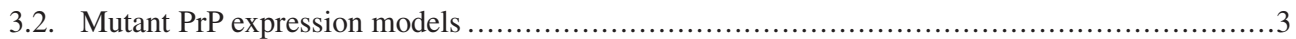

3.3. Transgenic mice overexpressing $\operatorname{PrP}^{\mathrm{C}}$ from heterologous species............................

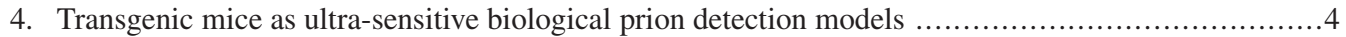

5. Assessment of species barrier effects in heterologous transgenic mouse infections ..................... 7

6. Phenotypic and/or biological evolution of prion strains as a consequence of transmissions to new

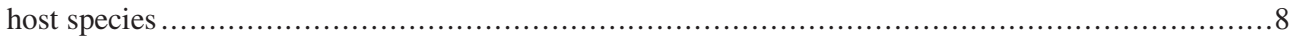

7. Transgenic mice as animal models to study the prion pathogenesis .............................. 9

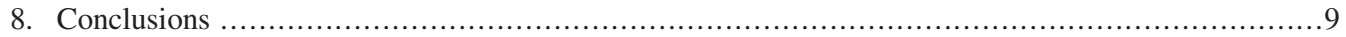

\section{INTRODUCTION}

Prion diseases in humans and animals can occur either spontaneously or following an in-

\footnotetext{
* Corresponding author:

martin.groschup@ fli.bund.de
}

fection. They are caused by prions, mainly if not entirely composed of $\operatorname{PrP}^{\mathrm{D}}$. $\mathrm{PrP}^{\mathrm{D}}$, commonly also designated PrPsc in reference to scrapie pions, is a misfolded form of a physiological protein [68] that is expressed in neuronal cells and many other cell types. $\mathrm{PrP}^{\mathrm{D}}$ 
is used as a diagnostic marker for transmissible spongiform encephalopathies (TSE) and studied in basic research. It has been reported that the accumulation of $\operatorname{PrP}^{\mathrm{D}}$ broadly correlates with the infectivity levels in a given tissue or sample [5], and it has even been shown for the hamster $263 \mathrm{~K}$ scrapie model that 14-28 coaggregated $\operatorname{PrP}^{\mathrm{D}}$ molecules are contained in one infectious unit [79]. However, it is well feasible that this correlation is valid only for particular combinations of prion strains and species, whereas correlations for other combinations are quite different. Indeed prion diseases have been described with no or only marginally detectable $\mathrm{PrP}^{\mathrm{D}}$ depositions in the brain of infected mice $[23,52]$. On the contrary, transmission of human TSE cases to transgenic mice can result in a massive $\mathrm{PrP}^{\mathrm{D}}$ accumulation in these mice without causing clinical disease [67]. Moreover, in some cases of bovine spongiform encephalopathy (BSE) in cattle, the intensity of the $\operatorname{PrP}^{\mathrm{D}}$ signal as determined by immunoblot does not mirror the amount of infectivity in the sample ${ }^{1}$. Therefore, there is no universal equation known to date for the number of $\operatorname{PrP}^{\mathrm{D}}$ molecules to one infectious unit. One major prerequisite for finding such an equation would be a better understanding of the infectious nature of prions eo ipso and the molecular mechanisms involved in their replication. This would also allow a better understanding and definition of $\operatorname{PrP}^{\mathrm{D}}$, which is primarily only defined biochemically by a prion strain specific partial protease resistance. For most prion strains, the experimental transmission to recipient animals is therefore still the only practical way to quantitatively determine the infectivity load and to describe the transmissibility properties. Until now, no cell culture system has been established that can be easily infected with prions derived from the original host species (cattle, sheep, goats, humans, etc.). So far only experimentally adapted TSE strains can be efficiently propagated in vitro.

In order to study the infectious nature of prions as well as the TSE susceptibility and pathogenesis in humans and animals, the ex-

\footnotetext{
${ }^{1}$ Buschmann A., Groschup M.H., Unpublished
} data. perimental use of in vivo models is a sine qua non. In vivo studies can either be carried out in the original animal host species or by transmission of the prions into heterologous species like laboratory rodents which are much easier to handle than ruminants for instance. Moreover, the recent progress in molecular biology techniques has allowed the design of transgenic mice, which are in particular aspects comparable to the natural host species. Other transgenic mouse models expressing prion protein mutants can be used to answer questions regarding the physiological function of the cellular prion protein and the pathomolecular mechanisms of prion diseases.

On the following pages an overview of the most recent advances for the different rodent models is given - with special emphasis on the use of genetically modified mice. Reviews on experimental ruminant and non-human primate models can be found in other papers in the special issue "Prion diseases in animals".

\section{CONVENTIONAL RODENT MODELS}

TSE transmission experiments to mice were first introduced in the 1960s [29, 90] and to hamsters in the 1970s [30]. Mice and hamsters have since then been the most frequently used experimental animals in TSE research, due to their much easier maintenance and shorter incubation times, and because they allow to discriminate and characterise prion strains. Prion strains are characterised by their biological features (transmissibility, incubation times, brain spongiform lesion profiles, and the topology and quality of the $\operatorname{PrP}^{\mathrm{D}}$ depositions) following transmission to a panel of conventional inbred (RIII, C57B1, VM) mice $[14,17,38,42]$. The same strain typing methodology has now also been applied to transgenic mice (e.g. $\operatorname{tg} a 20, \mathrm{TgbovXV}, \mathrm{Tg} 338$, Tgshp, Tgshp) as well as to bank voles [26, 66]. Bank voles (Clethrionomys glareolus) have recently been described to be as susceptible to a Creutzfeldt-Jakob disease (CJD) infection as human PrP transgenic mice [66], although there is only a comparably low sequence homology between the PrP of humans and bank voles. Research with this species will therefore be intensified in the future. The 
availability of inbred mouse strains played a very important role in the standardisation of brain lesion profiling and was crucial for the definition of the TSE strains. However, it must be noted that such a congruency in their genetic backgrounds does not usually exist for transgenic mice that commonly represent crosses of different inbred lines. TSE isolates can also be characterised biochemically on the basis of the glycosylation pattern, and proteinase $\mathrm{K}$ digestion profile (cleavage site as well as general resistance) of $\mathrm{PrP}^{\mathrm{D}}$. Most prion strains are stable when propagated within a given host species.

\section{TRANSGENIC MOUSE MODELS}

\subsection{PrP knockout models}

After the announcement of the prion hypothesis in 1982, considerable efforts were made to prove the involvement of this cellular protein in the prion pathogenesis and replication. This can best be shown by PrP knockout mice in which the expression of the physiological protein is genetically ablated. At least four different PrP knockout mice have been generated to date which differ in their genetic design [86]. They all prove that the $\operatorname{PrP}^{\mathrm{C}}$ expression is dispensable for the development and function of mammalian cells and organisms. However, the $\mathrm{PrP}^{\mathrm{C}}$ expression is crucially important for the prion replication and development of the disease since experimental challenge experiments on PrP knockout mice were unsuccessful [19]. Moreover, the successive inbreeding of a single $\operatorname{PrP}^{\mathrm{C}}$ allele into these knockout mice, which leads to an intermediate $\mathrm{PrP}^{\mathrm{C}}$ expression and in later studies the transgenic overexpression of mouse $\mathrm{PrP}^{\mathrm{C}}$ driven by the introduction of multiple prion gene copies into the mouse genome, showed that the $\operatorname{PrP}^{\mathrm{C}}$ expression rate is an important modulator for TSE susceptibility [36].

However, since animals of two PrP knockout mouse models also suffered from a Purkinje cell loss and ataxia, lessons were learned about the genetic regulation of another protein, the so-called Doppel protein. Doppel is encoded by a gene in the close vicinity of the prion gene. The prion gene ablation in these particular knock out mouse models led to an up-regulation of the Doppel expression in adult animals which causes these harmful effects [8]. Doppel is, however, not involved in prion pathogenesis and propagation [69].

\subsection{Mutant PrP expression models}

Reverse genetics on PrP knockout was used to introduce modified mouse or hamster genes to address a variety of questions:

- mapping PrP regions involved in or required for PrP conversion and prion replication $[36,37,44,56,57,63,78,80]$;

- studies on the physiological role of $\operatorname{PrPC}^{\mathrm{C}}$ and the contributions of individual molecular regions to these functions [65];

- studies on molecular aspects of species barrier effects by mutation of single or limited numbers of positions within the $\operatorname{PrP}$ [20, 41, 51, 76, 77, 82];

- modelling of familial forms of human prion diseases $[3,4,60]$;

- analysis of the cell specificity of prion propagation [48, 71, 72];

- analysis of the role of PrP glycosylation $[22,64]$;

- studies on the mechanisms of prion spread $[11,12]$;

- studies on the neuropathological roles of $\operatorname{PrP}^{\mathrm{C}}$ and of $\operatorname{PrP}^{\mathrm{D}}$ in prion disease [39];

- studies on the function of PrP Doppel [34].

All these complex studies have contributed enormously to a better understanding of the nature of prions.

\subsection{Transgenic mice overexpressing $\operatorname{PrP}^{\mathrm{C}}$ from heterologous species}

Many prion diseases can only be transmitted rather inefficiently from diseased to recipient animals, even under experimental conditions where inocula are injected parenterally by a simultaneous intraperitoneal (i.p.) and intracerebral (i.c.) route. The transmission efficiency is particularly low, if the recipient animal belongs to another species. This is usually the case since mostly rodent recipients were used for practical or ethical reasons. In such an experimental setup prions have to cross a considerable species barrier which results in a 
lower transmission efficiency (leading to extended incubation times). The primary amino acid sequence of a protein determines its folding structure and therefore defines the potential interaction sites on the molecular surface. In the case of prions, there is considerable evidence that the amino acid sequence homology of $\operatorname{PrP}^{\mathrm{C}}$ from the donor versus that of the recipient species determines the transmission efficiency. However, this efficiency is sometimes also influenced by strain specific effects. In order to overcome this sequence effect, a number of transgenic mouse models have been generated during the last two decades, which express $\mathrm{PrP}^{\mathrm{C}}$ of heterologous species. The seminal experiment was conducted by Scott et al. who have generated transgenic mice overexpressing hamster $\operatorname{PrP}^{\mathrm{C}}$ that proved other than conventional mice susceptible to 263K hamster prions [76]. Meanwhile a battery of transgenic mouse lines are available which express human, mink, bovine, ovine, caprine, cervid, and mouse $\operatorname{PrP}^{\mathrm{C}}$. A register of published susceptible transgenic mouse lines is compiled in Table I.

In principle, there are two approaches to generating transgenic mice: (a) by homologous recombination after transfecting murine stem cells which introduces the gene of interest exactly at the defined target site in the mouse genome; or (b) by microinjection of a transgenic DNA sequence encoding the gene of interest into the pronucleus of a mouse oocyte which leads to a multiple (usually head to tail) insertion array of the trangene randomly into the genome. Both techniques have their advantages and disadvantages.

An interesting phenomenon was observed when humanised transgenic mice were generated and challenged with CJD prions [76]. These mice were only susceptible when the murine $\operatorname{PrP}^{\mathrm{C}}$ expression was ablated or when the transgenically expressed human $\operatorname{PrP}^{\mathrm{C}}$ carried the murine aminoacid sequences at the carboxy-terminus. Scott et al. [76] postulated that there is a so-called factor X necessary for the conversion of human $\operatorname{PrP}^{\mathrm{C}}$ that is captured and blocked by the C-terminus of mouse $\operatorname{PrP}^{\mathrm{C}}$ if present. In order to avoid any interference with wild-type mouse $\operatorname{PrP}^{\mathrm{C}}$, most transgenic lines used today are therefore on a mouse $\mathrm{PrP}^{\mathrm{C}}$ ablated background.

\section{TRANSGENIC MICE AS ULTRA-SENSITIVE BIOLOGICAL PRION DETECTION MODELS}

According to the prion hypothesis, infectivity should be detectable using transgenic mice expressing the $\mathrm{PrP}^{\mathrm{C}}$ of the donor species at least as good as if animals of the original species were used. The best prion transmission rates were shown in transgenic mice in which $\operatorname{PrP}^{\mathrm{C}}$ is heavily overexpressed due to a multiple transgene copy insertion after pronucleus microinjection. However, it has been argued that the random insertion does not mimic the normal mouse $\operatorname{PrP}^{\mathrm{C}}$ expression pattern so that the prion disease pathogenesis may be affected. In order to at least partly overcome such random integration effects, large transgene vectors like the half genomic hgPrP vector (which is composed of the mouse prion gene $(12 \mathrm{~kb})$ in which the second intron is deleted) [10] or a cosmid encompassing the total hamster prion gene $(45 \mathrm{~kb})[75]$ are used for the generation of transgenic mice. Alternatively, $\operatorname{PrP}^{\mathrm{C}}$ is expressed under the control of cytomegalovirus (CMV) [85] or neuron specific enolase (NSE) [33] gene derived promoters. However, these transgenic mice usually do not display an authentic mouse $\operatorname{PrP}^{\mathrm{C}}$ expression pattern in body tissues like conventional mice.

The susceptibility of a transgenic mouse line can best be determined by a comparative parallel titration of a defined original inoculum in the transgenic mouse model and in the donor host species. Interestingly, a $\mathrm{PrP}^{\mathrm{C}}$ overexpression can even result in a higher sensitivity as compared to the original species. Comparative bioassays have been performed for CJD in monkeys [73] and for BSE in cattle $[21,87]$, and in each case the transgenic mouse bioassays revealed a 1-2 $\log \mathrm{LD}_{50}$ higher infectivity titre than the respective homologous species. Tgbov XV mice are currently the only transgenic mouse model for ruminant prions for which such a parallel titration is available. These mice were challenged by the i.c. route with a limited dilution series of a BSE brain 


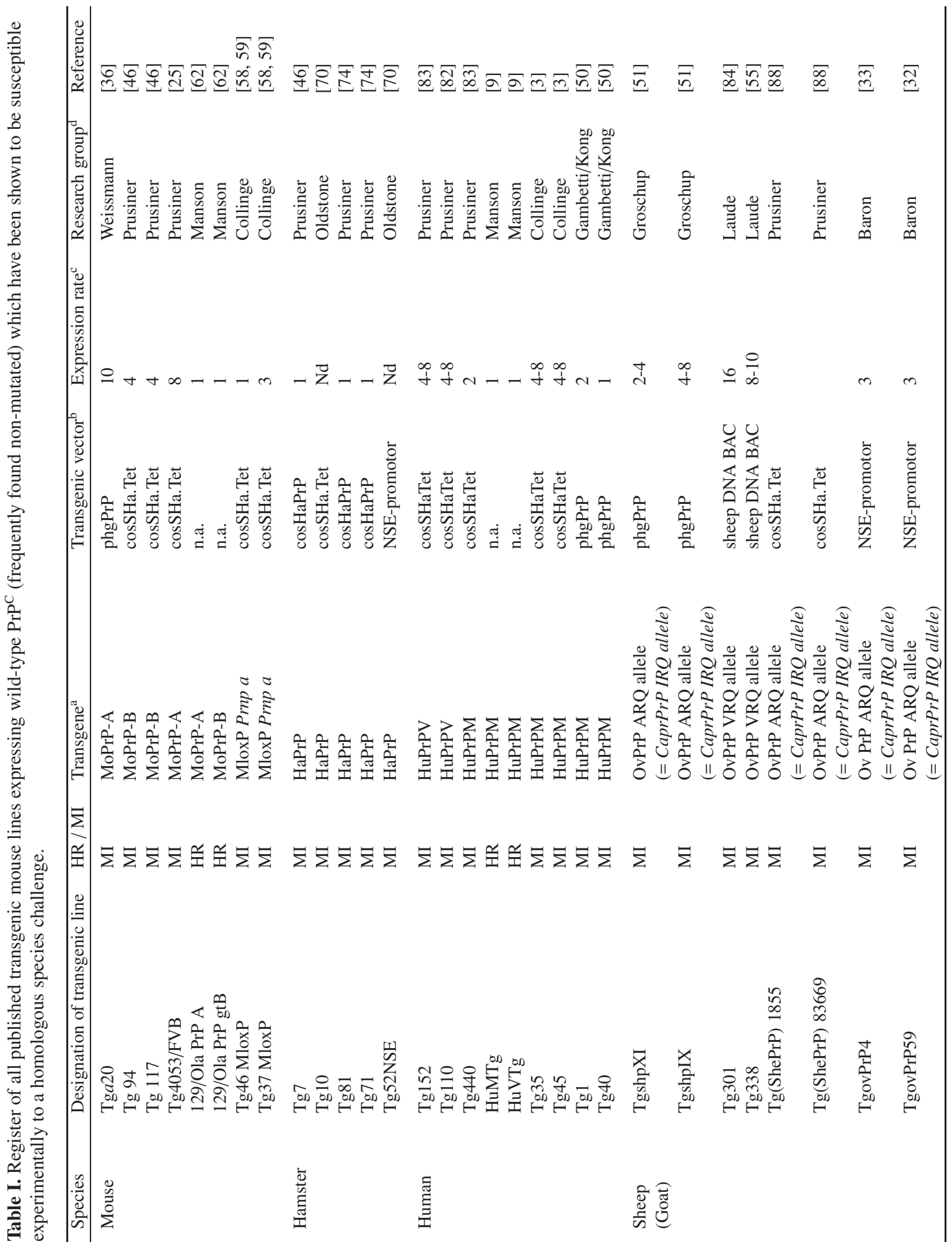




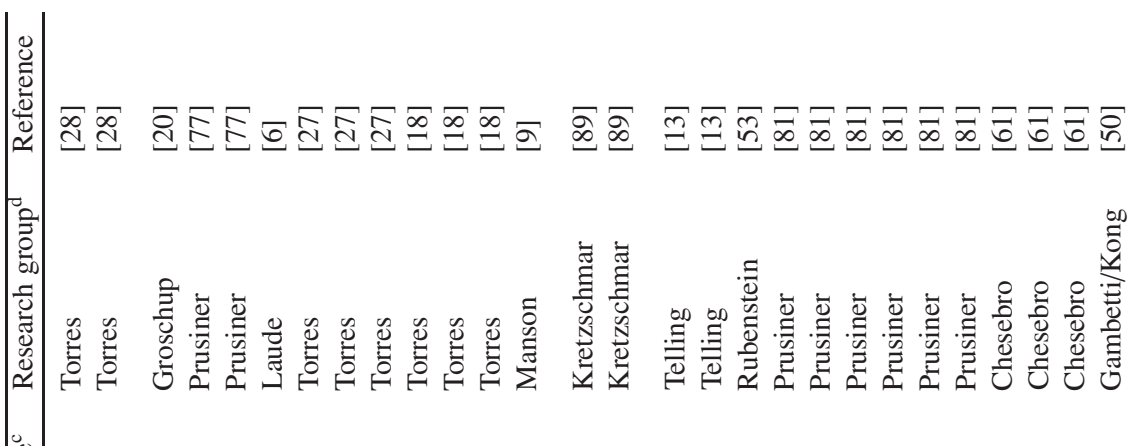

荇

鹿离

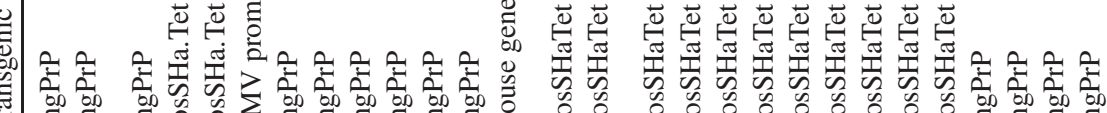

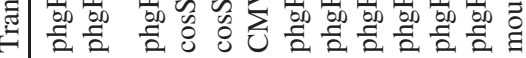

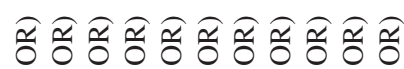
e e e e e e e e in

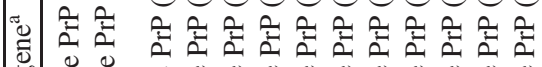

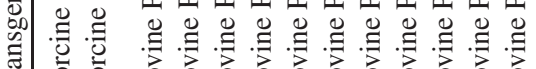

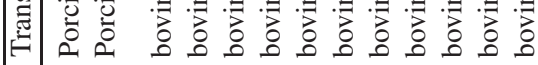

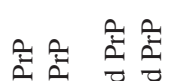

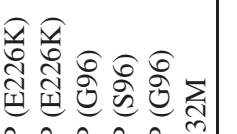

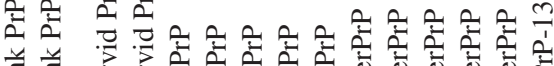

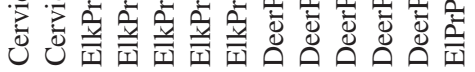

$\sum$

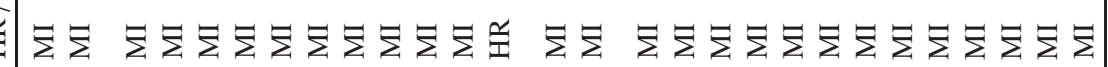

音

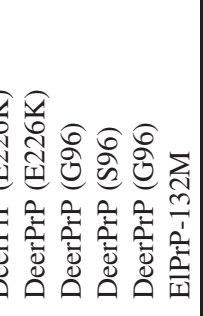

$\begin{array}{r}\dot{0} \\ 0 \\ 0 \\ 0 \\ 0 \\ \ddot{0} \\ \hline\end{array}$

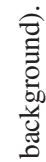

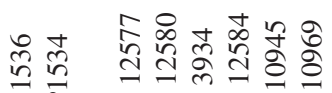

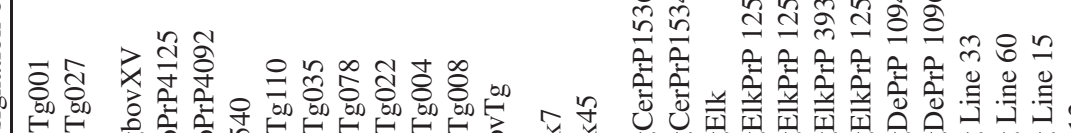

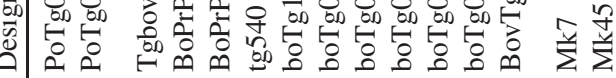

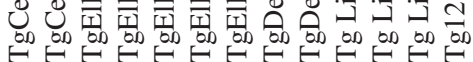


stem pool homogenate and an infectivity titre of $10^{7.8} \mathrm{ID}_{50} / \mathrm{g}$ was revealed. The same inoculum when titrated intracerebrally in cattle gave an infectivity titre of $10^{6} \mathrm{ID}_{50} / \mathrm{g}$. Since a titration for each inoculum is not always feasible in the original host species, a titration in a defined transgenic mouse line can be used and the transgenic line of interest can then be compared to this reference model. However, even such data are not available for most transgenic mouse lines at present. It must therefore be emphasised that the standardisation by comparative titration of inocula in the original host species and in transgenic mouse models is one of the major tasks for the future in order to facilitate a better appreciation of the many experimental data published on infectivity levels in tissues and bodily fluids of prion diseased animals and humans.

The determination of the susceptibility of transgenic mice is even more important in the light of conflicting evidence speaking against the amino acid homology hypothesis that has been published lately. In a comparative titration of sheep-passaged BSE infectivity in Romney sheep and in RIII mice, the sheepto-mouse species barrier was lower than anticipated and similar infectivity titres were obtained for both sheep $10^{5.4}$ (i.c.) $\mathrm{ID}_{50} / \mathrm{g}$ and mice $10^{5.0}$ (i.c + i.p.) ID $_{50} / g$ [40]. Moreover, it has been suggested that the increased susceptibility of transgenic mice results rather from the heterologous $\mathrm{PrP}^{\mathrm{C}}$ overexpression than from a homology effect. However, challenging transgenic mice overexpressing murine $\operatorname{PrP}^{\mathrm{C}}$ (tga20 mice) with BSE did not result in a remarkable reduction of the incubation time $[20,21]$. Answering these questions will not only help define to the most sensitive detection models for human and animal prions but also will shed light on the mechanisms of the prion replication itself.

\section{ASSESSMENT OF SPECIES BARRIER EFFECTS IN HETEROLOGOUS TRANSGENIC MOUSE INFECTIONS}

Species barrier effects are frequently estimated on the basis of the incubation times in primary transmission studies and on the reduction in the second passage. However, these data must be interpreted with particular care, since incubation times are crucially dependent on the infectivity levels in the samples used. A low infectivity load in the inoculum causes a long incubation time, while a high challenge dose causes a short incubation time in the recipient transgenic mice. Likewise, an efficient initial prion replication in transgenic mice generates a highly infectious subpassage inoculum, which itself yields a shorter incubation time as compared to that of the original inoculum, independently from any species adaptation effect. In stricto sensu incubation time differences can therefore only be interpreted as species barrier effects, if TSE isolates of compatible infectivity titres are used in all transmission studies and if it can be verified that compatible $\mathrm{PrP}^{\mathrm{C}}$ expression patterns are present in the transgenic mice.

Moreover, the following aspects should be kept in mind when interpreting such transmission data:

- Depending on the experimental setup, there can be quite a range of incubation time variations in cross species barrier transmission experiments. This is particularly true if only low numbers of recipient mice are used, if the general incubation time in this model is quite long and if the differences in the individual mice of the challenge group are comparatively wide. From the authors experience, it is advised to use at least ten mice per group if incubation times are expected to lie within half of the mouse's natural life span, and 15 animals if longer incubation times are expected.

- The reduction of the incubation time after primary passage versus subpassage is dependent on prion strain specific effects. This has been described in detail for BSE and sheep scrapie in transmission studies to RIII, C57Bl, and VM mice [16]. While the primary transmission can be accompanied with quite long incubation times, the subpassages can, depending on the prion strain, result in short, intermediate, or long incubation times.

- An interspecies transmission to transgenic mice (e.g. scrapie transmission to 
bovinised mice) does not necessarily lead to prolonged incubation times as compared to an intraspecies transmission (e.g. BSE transmission to bovinised mice). The underlying mechanism is still largely unknown, but from various experiments, it can be assumed that this effect is not only due to the infectivity titres of the applied inocula.

- The absolute length of the incubation period must not necessarily correlate with the susceptibility of the mouse line but is also prion strain dependent. Even in bovinised transgenic mice serially passaged BSE prions show longer incubation times than many scrapie strains. Transgenic mouse lines displaying a short incubation period with a given prion strain must therefore not necessarily have a high susceptibility to all other strains derived from the same species. For example in Tg338 mice overexpressing ovine $\operatorname{PrP}^{\mathrm{C}}$ (VRQ allele), incubation times for primary ovine scrapie isolates can vary from 60 days (ARQ allele PG127) [84] to well over 600 days (for individual Italian scrapie isolates) ${ }^{2}$. However, a prion strain with a shorter incubation time has the potential to be detected more efficiently since the natural life span of a mouse is limited to approximately two years. Low infectivity doses of prion strains with extremely long incubation times may therefore simply be missed when the mice die naturally before the end of the incubation time.

\section{PHENOTYPIC AND/OR BIOLOGICAL EVOLUTION OF PRION STRAINS AS A CONSEQUENCE OF TRANSMISSIONS TO NEW HOST SPECIES}

Transmissions across species barriers can alter the characteristics of prion strains. It has been suggested that the transmission of scrapie between species may be associated with a permanent change in the strain phenotype, due to a selection or to a mutation of the prion strain $[15,31]$. According to the selection concept, prion strains are composed of a mix of different variants and the propagation across

${ }^{2}$ Laude H., personal communication. a transmission barrier favours one or another subset of variants with a higher or lower efficiency. Since changes in prion strains were observed even when cloned scrapie strains were used, this was attributed to a mutation in the infectious agent. However, the discrimination between selection and mutation processes seems somewhat arbitrary as long as it cannot be excluded that even cloned prion strains might be composed of a variety of subsets [49]. It can be assumed that for most if not all published transmission experiments, accidental transmissions of a different TSE strain by contamination of instruments or other equipment can be excluded, as usually stated in the methods section. This enigma will only be resolved when the nature of prion strain determining factors are completely understood and can be measured directly (and not only by bystander effects). Evolution of strain characteristics following interspecies transmissions have been reported for experimental hamster scrapie strains and for sheep scrapie isolates [49]. The transmission of cattle-derived BSE to $\mathrm{C} 57 \mathrm{~B} 16$ mice has produced the experimental BSE strain 301C while the transmission to VM mice generated $301 \mathrm{~V}$ prions. However, BSE proved quite stable, i.e. represented only one defined strain when reisolated from a variety of species (including vCJD in humans) which were infected during the course of the BSE epidemic in the UK. Asante et al. [3] have reported that the transmission of BSE to $\mathrm{Tg} 35$ mice overexpressing human $\mathrm{PrP}^{\mathrm{C}}$ produced primarily the well known vCJD $\operatorname{PrP}^{\mathrm{D}}$ phenotype, but also in low numbers a second phenotype (distinguished by biochemical and anatomical analysis of the $\operatorname{PrP}^{\mathrm{D}}$ deposits) which was reminiscent of sporadic CJD $\operatorname{PrP}^{\mathrm{D}}$. Another publication describes the transmission of a new bovine prion strain called bovine amyloidotic spongiform encephalopathy (BASE), which can be discriminated from BSE mainly on the basis of a lower molecular mass of the unglycosylated form of $\operatorname{PrP}^{\mathrm{D}}$, a different anatomical distribution of the accumulated $\operatorname{PrP}^{\mathrm{D}}$ in the brain, and by the presence of PrP immunoreactive amyloid plaques, bovine PrP transgenic mice. Surprisingly, passage of this strain in conventional 
mice produced $\mathrm{PrP}^{\mathrm{D}}$ of the $\mathrm{BSE}$ phenotype, while bovine PrP transgenic mice revealed the $\operatorname{PrP}^{\mathrm{D}}$ signature of the BASE type [24]. Moreover, in a similar study, BASE prions acquired strain features closely similar to those of BSEtype agents when propagated in mice expressing ovine $\operatorname{PrP}(\mathrm{Tg} 338)$, although they retained the BASE-associated phenotypic traits in other lines, including bovine PrP mice [7]. Finally, Espinosa et al. [35] studied the effect of an interim passage of BSE prions in sheep carrying a PrP allele encoding alanine at codon 136, arginine at codon 154 and glutamine at codon 171 ( $\mathrm{PrP}^{\mathrm{ARQ}}$ ) in homozygosity prior to the inoculation into bovinised transgenic mice, and observed that this interim passage altered the transmission phenotype of the BSE prions. Cattle derived BSE produced an incubation time of 303 days in the bovinised mice, while sheep derived BSE was shorter with only 234 days. Infectivity titre effects are improbable, since this incubation time difference was similar after subpassage ( 290 days and 234 days) in the same transgenic mouse line. Biochemical signature, lesion profile, and $\mathrm{PrP}^{\mathrm{D}}$ deposition pattern of both cattle and sheep BSE were similar. The observation that ovine BSE but not ovine scrapie isolates lack a species barrier to bovinised transgenic mice illustrates how little the concept of species barrier and strain specific effects is understood to date.

\section{TRANSGENIC MICE AS ANIMAL MODELS TO STUDY THE PRION PATHOGENESIS}

The question of TSE pathogenesis has been addressed by using transgenic mice produced by microinjection or by homologous recombination. The latter approach is certainly leading to a more authentic $\operatorname{PrP}^{\mathrm{C}}$ expression in the transgenic mouse as compared to conventional mice. However, most factors which modulate the pathogenesis of prion infections in vivo are still an enigma. It is well feasible that prions enter the organism most frequently via the oral route. The infectious agents thereby have to overcome the gut wall barrier, replicate locally in the lymphoreticular system (LRS) of the gastrointestinal tract and then travel by one or more routes to the central nervous system. In the gut associated lymphoid tissues, early agent-specific $\operatorname{PrP}^{\mathrm{D}}$ accumulation occurs within the germinal centres of B-cell follicles on follicular dendritic cells (FDC) and also within macrophages. Since neuroinvasion is delayed and disease susceptibility is reduced in the absence of FDC, the initial prion replication in FDC seems to be crucial. Likewise are B-cells that provide important cytokine stimuli such as membrane lymphotoxin (LT) $\alpha 1 \beta 2$ and tumour-necrosis factor (TNF) $\alpha$, which maintain the FDC in their differentiated state. It is clear today that FDC in the LRS play the decisive role at least at the site of entry, if not in the whole organism for the success and effectiveness of the prion infection. Various transgenic mouse models carrying mutations that affect their immune system have played an important role in elaborating today's understanding of these events (for review see [1]). However, most of these studies have been carried out by using a limited number of experimental murine prion strains, whereas little is known about the pathogenesis and infectivity distribution of other prion strains. Moreover, there is a number of major or minor differences (mostly still to be discovered) in the prion pathogenesis in other mammalian species given their evolutionary distance (from humans, bovines, sheep, goats to cervids). Grossly speaking, prions seem to replicate preferentially, if not entirely, in the nervous system in cattle, while there can be a strong lymphatic component in sheep, goats, and cervids. However, this is not a universal rule, because within the same species differences can be enormous, e.g. depending on the prion haplotype that an animal carries. For example, prions replicate in the LRS of sheep carrying two $\operatorname{PrP}^{\mathrm{VRQ}}$ or $\operatorname{PrP}^{\mathrm{ARQ}}$ haplotypes while the replication seems to be more restricted to the nervous system in sheep carrying at least one $\mathrm{PrP}^{\mathrm{ARR}}$ haplotype [2, 43, $45,47,54]$.

\section{CONCLUSIONS}

The development of transgenic mouse models for prion diseases has been a major step forward for the detection of infectivity in naturally affected species for which intraspecies 
transmission studies are unavailable or impratical. While transgenic mouse (independent of whether they were generated by homologous recombination or by microinjection), bank vole, or hamster models are not bona fide models for the prion pathogenesis in humans and animals, they can allow to make better exposure and transmission risk assessments for animals and humans. Studying the scrapie pathogenesis in these rodent models can shed light on the principal mechanisms of prion replication and disease. This knowledge may be useful to explain the pathogenetic mechanisms in the original host species and strain combinations.

\section{REFERENCES}

[1] Aguzzi A., Heikenwalder M., Pathogenesis of prion diseases: current status and future outlook, Nat. Rev. Microbiol. (2006) 4:765-775.

[2] Andréoletti O., Berthon P., Levavasseur E., Lantier F., Monks E., Elsen J.M., Schelcher F., Phenotyping of protein-prion (PrPSc)-accumulating cells in lymphoid and neural tissues of naturally scrapie-affected sheep by double-labeling immunohistochemistry, J. Histochem. Cytochem. (2002) 50:1357-1370.

[3] Asante E.A., Linehan J.M., Desbruslais M., Joiner S., Gowland I., Wood A.L., et al., BSE prions propagate as either variant CJD-like or sporadic CJD-like prion strains in transgenic mice expressing human prion protein, EMBO J. (2002) 21:6358-6366.

[4] Asante E.A., Linehan, J. M., Gowland I., Joiner S., Fox K., Cooper S., et al., Dissociation of pathological and molecular phenotype of variant Creutzfeldt-Jakob disease in transgenic human prion protein 129 heterozygous mice, Proc. Natl. Acad. Sci. USA (2006) 103:10759-10764.

[5] Beekes M., Baldauf E., Diringer H., Sequential appearance and accumulation of pathognomonic markers in the central nervous system of hamsters orally infected with scrapie, J. Gen. Virol. (1996) 77:19251934.

[6] Beringue V., Bencsik A., Le Dur A., Reine F., Lai T.L., Chenais N., et al., Isolation from cattle of a prion strain distinct from that causing bovine spongiform encephalopathy, PLoS Pathog. (2006) 2:956-963.

[7] Béringue V., Andréoletti O., Le Dur A., Essalmani R., Vilotte J.L., Lacroux C., et al., A bovine prion acquires an epidemic bovine spongiform encephalopathy strain-like phenotype on interspecies transmission, J. Neurosci. (2007) 27:6965-6871.

[8] Al Bersaoui R., Robert I., Lutz Y., Blanc F., Sommermeyer-Leroux G., Shibaguchi H., et al., Purkinje-cell degeneration in prion protein-deficient mice is associated with a cerebellum-specific Doppel protein species signature, FEBS Lett. (2005) 9:27152721.
[9] Bishop M.T., Hart P., Aitchison L., Baybutt H.N., Plinston C., Thomson V., et al., Predicting susceptibility and incubation time of human-to-human transmission of vCJD, Lancet Neurol. (2006) 5:393-398.

[10] Borchelt D.R., Davis J., Fischer M., Lee M.K., Slunt H.H., Ratovitsky T., et al., A vector for expressing foreign genes in the brains and hearts of transgenic mice, Genet. Anal. (1996) 13:159-163.

[11] Brandner S., Isenmann S., Raeber A., Fischer M., Sailer A., Kobayashi Y., et al., Normal host prion protein necessary for scrapie-induced neurotoxicity, Nature (1996) 379:339-343.

[12] Brandner S., Raeber A., Sailer A., Blättler T., Fischer M., Weissmann C., Aguzzi A., Normal host protein $\left(\mathrm{PrP}^{\mathrm{C}}\right)$ is required for scrapie spread within the central nervous system, Proc. Natl. Acad. Sci. USA (1996) 93:13148-13151.

[13] Browning S.R., Mason G.L., Seward T., Green M., Eliason G.A., Mathiason C., et al., Transmission of prions from mule deer and elk with chronic wasting disease to transgenic mice expressing cervid PrP, J. Virol. (2004) 78:13345-13350.

[14] Bruce M.E., Mc Connell I., Fraser H., Dickinson A.G., The disease characteristics of different strains of scrapie in Sinc congenic mouse lines: implications for the nature of the agent and host control of pathogenesis, J. Gen. Virol. (1991) 72:595-603.

[15] Bruce M.E., Scrapie strain variation and mutation, Br. Med. Bull. (1993) 49:822-838.

[16] Bruce M.E., Boyle A., Cousens S., McConnell I., Foster J., Goldmann W., Fraser H., Strain characterization of natural sheep scrapie and comparison with BSE, J. Gen. Virol. (2002) 83:695-704.

[17] Bruce M.E., TSE strain variation, Br. Med. Bull. (2003) 66:99-108.

[18] Brun A., Gutierrez-Adan A., Castilla J., Pintado B., Segundo F.D.S., Cano M.J., et al., Reduced susceptibility to bovine spongiform encephalopathy prions in transgenic mice expressing a bovine PrP with five octapeptide repeats, J. Gen. Virol. (2007) 88:1842-1849.

[19] Büeler H., Fischer M., Lang Y., Bluethmann H., Lipp H.P., DeArmond S.J., et al., Normal development and behaviour of mice lacking the neuronal cell-surface PrP protein, Nature (1992) 356:577-582.

[20] Buschmann A., Pfaff E., Reifenberg K., Muller H.M., Groschup M.H., Detection of cattle-derived BSE prions using transgenic mice overexpressing bovine $\operatorname{PrP}(\mathrm{C})$, Arch. Virol. Suppl. (2000) 16:75-86.

[21] Buschmann A., Groschup M.H., Highly bovine spongiform encephalopathy-sensitive transgenic mice confirm the essential restriction of infectivity to the nervous system in clinically diseased cattle, J. Infect. Dis. (2005) 192:934-942.

[22] Cancelotti E., Wiseman F., Tuzi N.L., Baybutt H., Monaghan P., Aitchison L., et al., Altered glycosylated PrP proteins can have different neuronal trafficking in brain but do not acquire scrapie-like properties, J. Biol. Chem. (2005) 280:42909-42918. 
[23] Cancellotti E., Barron R.M., Bishop M.T., Hart P., Wiseman F., Manson J.C., The role of host PrP in transmissible spongiform encephalopathies, Biochim. Biophys. Acta (2007) 1772:673-680.

[24] Capobianco R., Casalone C., Suardi S., Manieri M., Miccolo C., Limido L., et al., Conversion of the BASE prion strani into the BSE strani: the origin of BSE?, PLoS Pathog. (2007) 3:31.

[25] Carlson G.A., Ebeling C., Yang S.L., Telling G., Torchia M., Groth D., et al., Prion isolate specified allotypic interactions between the cellular and scrapie prion proteins in congenic and transgenic mice, Proc. Natl. Acad. Sci. USA (1994) 91:5690-5694.

[26] Cartoni C., Schinina M.E., Maras B., Nonno R., Vaccari G., Di Baria M.A., et al., Identification of the pathological prion protein allotypes in scrapie-infected heterozygous bank voles (Clethrionomys glareolus) by high-performance liquid chromatography-mass spectrometry, J. Chromatogr. A (2005) 1081:122-126.

[27] Castilla J., Gutierrez A.A., Brun A., Pintado B., Ramirez M.A., Parra B., et al., Early detection of $\operatorname{PrP}($ res $)$ in BSE-infected bovine PrP transgenic mice, Arch. Virol. (2003) 148:677-691.

[28] Castilla J., Gutierrez-Adan A., Brun A., Doyle D., Pintado B., Ramirez M.A., et al., Subclinical bovine spongiform encephalopathy infection in transgenic mice expressing porcine prion protein, J. Neurosci. (2004) 24:5063-5069.

[29] Chandler R.L., Encephalopathy in mice produced by inoculation with scrapie-brain material, Lancet (1961) 1:1378-1379.

[30] Chandler R.L., Turfrey B.A., Inoculation of voles, Chinese hamsters, gerbils and guinea-pigs with scrapie brain material, Res. Vet. Sci. (1972) 13:219-224.

[31] Collinge J., Clarke A.R., A general model of prion strains and their pathogenecity, Science (2007) 318:930-936.

[32] Cordier C., Bencsik A., Philippe S., Betemps D., Ronzon F., Calavas D., et al., Transmission and characterization of bovine spongiform encephalopathy sources in two ovine transgenic mouse lines (TgOvPrP4 and TgOvPrP59), J. Gen. Virol. (2006) 87:3763-3771.

[33] Crozet C., Flamant F., Bencsik A., Aubert D., Samarut J., Baron T., Efficient transmission of two different sheep scrapie isolates in transgenic mice expressing the ovine PrP gene, J. Virol. (2001) 75:53285334.

[34] Dong J., Li A., Yamaguchi N., Sakaguchi S., Harris D.A., Doppel induces degeneration of cerebellar Purkinje cells independently of Bax, Am. J. Pathol. (2007) 171:599-607.

[35] Espinosa J.C., Andréoletti O., Castilla J., Herva M.E., Morales M., Alamillo E., et al., Sheep-passaged bovine spongiform encephalopathy agent exhibits altered pathobiological properties in bovine-PrP transgenic mice, J. Virol. (2007) 81:835-843.
[36] Fischer M., Rulicke T., Raeber A., Sailer A., Moser M., Oesch B., et al., Prion protein (PrP) with amino-proximal deletions restoring susceptibility of PrP knockout mice to scrapie, EMBO J. (1996) 15:1255-1264.

[37] Flechsig E., Shmerling D., Hegyi I., Raeber A.J., Fischer M., Cozzio A., et al., Prion protein devoid of the octapeptide repeat region restores susceptibility to scrapie in PrP knockout mice, Neuron (2000) 27:399408.

[38] Fraser H., Dickinson A.G., Scrapie in mice. Agent-strain differences in the distribution and intensity of grey matter vacuolation, J. Comp. Pathol. (1973) 83:29-40.

[39] Glatzel M., Aguzzi A., $\operatorname{PrP}^{\mathrm{C}}$ expression in the peripheral nervous system is a determinant of prion neuroinvasion, J. Gen. Virol. (2000) 81:2813-2821.

[40] Gonzalez L., Chianini F., Martin S., Siso S., Gibbard L., Reid H.W., Jeffrey M., Comparative titration of experimental ovine BSE infectivity in sheep and mice, J. Gen. Virol. (2007) 88:714-717.

[41] Gorfe A.A., Caflisch A., Ser170 controls the conformational multiplicity of the loop 166-175 in prion proteins: implication for conversion and species barrier, FASEB J. (2007) 21:3279-3287.

[42] Groschup M.H., Geissen M., Buschmann A., The experimental transmissibility of prions and infectivity distribution in the body, in: Hoernlimann B., Riesner D., Kretzschmar H. (Eds.), Prions in humans and animals, De Gruyter Berlin, New York, 2007, pp. 473482.

[43] Groschup M.H., Lacroux C., Buschmann A., Lühken G., Mathey J., Eiden M., et al., Classical scrapie in sheep with the ARR/ARR prion genotype in Germany and France, Emerging Infect. Dis. (2007) 13:1201-1207.

[44] Hedge R.S., Masrianni J.A., Scott M.R., DeFea K.A., Tremblay P., Torchia M., et al., A transmembrane form of the prion protein in neurodegenerative disease, Science (1998) 279:827-834.

[45] Houston E.F., Halliday S.I., Jeffrey M., Goldmann W., Hunter N., New Zealand sheep with scrapiesusceptible PrP genotypes succumb to experimental challenge with a sheep-passaged scrapie isolate (SSBP/1), J. Gen. Virol. (2002) 83:1247-1250.

[46] Hsiao K.K., Scott M., Foster D., Groth D.F., DeArmond S.J., Prusiner S.B., Spontaneous neurodegeneration in transgenic mice with mutant prion protein, Science (1990) 250:1587-1590.

[47] Jeffrey M., Begara-McGorum I., Clark S., Martin S., Clark J., Chaplin M., Gonzales L., Occurrence and distribution of infection-specific PrP in tissues of clinical scrapie cases and cull sheep from scrapie-affected farms in Shetland, J. Comp. Pathol. (2002) 127:264273.

[48] Kercher L., Favara C., Striebel J.F., LaCasse R., Chesebro B., Prion protein expression differences in 
microglia and astroglia influence scrapie-induced neurodegeneration in the retina of transgenic mice, J. Virol. (2007) 81:10340-10351.

[49] Kimberlin R.H., Cole S., Walker C.A., Temporary and permanent modifications to a single strain of mouse scrapie on transmission to rats and hamsters, J. Gen. Virol.(1987) 68:1875-1881.

[50] Kong Q., Huang S., Zou W., Vanegas D., Wang M., Wu D., et al., Chronic wasting disease of elk: transmissibility to humans examined by transgenic mouse models, J. Neurosci. (2005) 25:7944-7949.

[51] Kupfer L., Eiden M., Buschmann A., Groschup M.H., Amino acid sequence and prion strain specific effects on the in vitro and in vivo convertibility of ovine/murine and bovine/murine prion protein chimeras, Biochim. Biophys. Acta (2006) 1772:704713.

[52] Lasmezas C.I., Deslys J.-P., Robain O., Jaegly A., Béringue V., Peyrin J.M., et al., Transmission of the BSE agent to mice in the absence of detectable abnormal prion protein, Science (1997) 275:402-405.

[53] LaFauci G., Carp R.I., Meeker H.C., Ye X., Kim J.I., Natelli M., et al., Passage of chronic wasting disease prion into transgenic mice expressing Rocky Mountain elk (Cervus elaphus nelsoni) PrPC, J. Gen. Virol. (2006) 87:3773-3780.

[54] Langeveld J.P.M., Jacobs J.G., Erkens J.H.F., Bossers A., van Zijderfeld F.G., van Keulen L.J.M., Rapid and discriminatory diagnosis of scrapie and BSE in retro-pharyngeal lymph nodes of sheep, BMC Vet. Res. (2006) 2:19.

[55] Laude H., Vilette D., Le Dur A., Archer F., Soulier S., Besnard N., Essalmani R., Vilotte J.L., New in vivo and ex vivo models for the experimental study of sheep scrapie: development and perspectives, C. R. Acad. Sci. III, Sci. Vie (2002) 325:49-57.

[56] Li A., Piccardo P., Barmada S.J., Ghetti B., Harris D.A., Prion protein with an octapeptide insertion has impaired neuroprotective activity in transgenic mice, EMBO J. (2007) 6:2777-2785.

[57] Li A., Christensen H.M., Stewart L.R., Roth K.A., Chiesa R., Harris D.A., Neonathal lethality in transgenic mice expressing prion protein with a deletion of residues 105-125, EMBO J. (2007) 26:548-558.

[58] Mallucci G.R., Ratte S., Asante E.A., Linehan J., Gowland I., Jefferys J.G., Collinge J., Post-natal knockout of prion protein alters hippocampal CA1 properties, but does not result in neurodegeneration, EMBO J. (2002) 21:202-210.

[59] Mallucci G., Dickinson A., Linehan J., Klohn P.C., Brandner S., Collinge J., Depleting neuronal PrP in prion infection prevents disease and reverses spongiosis, Science (2003) 302:871-874.

[60] Manson J.C., Jamieson E., Baybutt H., Tuzi N.L., Barron R., McConnell I., et al., A single amino acid alteration $(101 \mathrm{~L})$ introduced into murine PrP dramatically alters incubation time of transmissible songiform encephalopathy, EMBO J. (1999) 18:6855-6864.
[61] Meade-White K., Race B., Trifilo M., Bossers A., Favara C., LaCasse R. et al., Resistance to chronic wasting disease in transgenic mice expressing a naturally occurring allelic variant of deer prion protein, $\mathrm{J}$. Virol. (2007) 81:4533-4539.

[62] Moore R.C., Hope J., McBride P.A., McConnell I., Selfridge J., Melton D.W., Manson J.C., Mice with gene targetted prion protein alterations show that Prnp, Sinc and Prni are congruent, Nat. Genet. (1998) 18:118-125.

[63] Muramoto T., DeArmond S.J., Scott M., Telling G.C., Cohen F., Prusiner S.B., Heritable disorder resembling neuronal storage disease in mice expressing prion protein with deletion of an $\alpha$-helix, Nat. Med. (1997) 3:750-755.

[64] Neuendorf E., Weber A., Saalmüller A., Schätzl H., Reifenberg K., Pfaff E., Groschup M.H., Glycosylation deficiency at either one of the two glycan attachement sites of cellular prion protein preserves susceptibility to bovine spongiform encephalopathy and scrapie infections, J. Biol. Chem. (2004) 279:53306-53316.

[65] Nishida N., Tremblay P., Sugimoto T., Shigematsu K., Shirabe S., Petromilli C., et al., A mouse prion protein transgene rescues mice deficient for the prion protein gene from purkinje cell degeneration and demyelinisation, Lab. Invest. (1999) 79:689-697.

[66] Nonno R., Di Bari M.A., Cardone F., Vaccai G., Fazzi P., Dell'omo G., et al., Efficient transmission and characterization of Creutzfeldt-Jacob disease strains in bank voles, PLoS Pathog. (2006) 2:112-120.

[67] Piccardo P., Manson J.C., King D., Ghetti B., Barron R.M., Accumulation of prion protein in the brain that is not associated with transmissible disease, Proc. Natl. Acad. Sci. USA (2007) 104:4712-4717.

[68] Prusiner S.B., Novel proteinaceous infectious particles cause scrapie, Science (1982) 216:136-144.

[69] Qin K., O'Donnell M., Zhao R.Y., Doppel: more rival than double to prion, Neuroscience (2006) 141:1-8.

[70] Race R.E., Priola S.A., Bessen R.A., Ernst D., Dockter J., Rall G.F., et al., Neuron-specific expression of a hamster prion protein minigene in transgenic mice induces susceptibility to hamster scrapie agent, Neuron (1995) 15:1183-1191.

[71] Race R., Oldstone M., Chesebro B., Entry versus blockade of brain infection following oral or intraperitoneal scrapie administration: role of prion protein expression in peripheral nerves and spleen, J. Virol. (2000) 74:828-833.

[72] Raeber A.J., Sailer A., Hegyi I., Klein M.A., Rülicke T., Fischer M., et al., Ectopic expression of prion protein $(\mathrm{PrP})$ in $\mathrm{T}$ lymphocytes or hepatocytes of PrP knockout mice is insufficient to sustain prion replication, Proc. Natl. Acad. Sci. USA (1999) 96:39873992.

[73] Safar J.G., Geschwind M.D., Deering C., Didorenko S., Sattavat M., Sanchez H., et al., 
Diagnosis of human prion disease, Proc. Natl. Acad. Sci. USA (2005) 102:3501-3506.

[74] Scott M., Foster D., Mirenda C., Serban D., Coufal F., Walchli M., et al., Transgenic mice expressing hamster prion protein produce species- specific scrapie infectivity and amyloid plaques, Cell (1989) 59:847-857.

[75] Scott M. Kohler R., Foster D., Prusiner S.B., Chimeric prion protein expression in cultured cells and transgenic mice, Protein Sci. (1992) 1:986-997.

[76] Scott M., Groth D., Foster D., Torchia M., Yang S.L., DeArmond S.J., Prusiner S.B., Propagation of prions with artificial properties in transgenic mice expressing chimeric PrP genes, Cell (1993) 73:979-988.

[77] Scott M.R., Safar J., Telling G., Nguyen O., Groth D., Torchia M., et al., Identification of a prion protein epitope modulating transmission of bovine spongiform encephalopathy prions to transgenic mice, Proc. Natl. Acad. Sci. USA (1997) 94:14279-14284.

[78] Shmerling D., Hegyi I., Fischer M., Blättler T., Brandner S., Götz J., et al., Expression ofaminoterminally truncated $\operatorname{PrP}$ in the mouse leading to ataxia and specific cerebellar lesions, Cell (1998) 93:203214.

[79] Silveira J.R., Raymond G.J., Hughson A.G., Race R.E., Sim V.L., Hayes S.F., Caughey, B., The most infectious prion protein particles, Nature (2005) 437:257-261.

[80] Supattapone S., Bosque P., Muramoto T., Wille, H. Aagaard C., Peretz D., et al., Prion protein of 106 residues creates an artificial transmission barrier for prion replication in transgenic mice, Cell (1999) 96:869-878.

[81] Tamguney G., Giles K., BouzamondoBernstein E., Bosque P.J., Miller M.W., Safar J., et al.,Transmission of elk and deer prions to transgenic mice, J. Virol. (2006) 80:9104-9114.

[82] Telling G.C., Scott M. Hsiao K.K., Foster D., Yang S.L., Torchia M., et al., Transmission of
Creutzfeldt-Jakob disease from humans to transgenic mice expressing chimeric human-mouse prion protein, Proc. Nat. Acad. Sci. U. S. A. (1994) 91:9936-9940.

[83] Telling G.C., Scott M., Mastrianni J., Gabizon R., Torchia M., Cohen F.E., et al., Prion propagation in mice expressing human and chimeric PrP transgenes implicates the interaction of cellular PrP with another protein, Cell (1995) 83:79-90.

[84] Vilotte J.L., Soulier S., Essalmani R., Stinnakre M.G., Vaiman D., Lepourry L., et al., Markedly increased susceptibility to natural sheep scrapie of transgenic mice expressing ovine PrP, J. Virol. (2001) 75:5977-5984

[85] Vilotte J.L., Laude H., Transgenesis applied to transmissible spongiform encephalopathies, Transgenic Res. (2002) 11:547-564.

[86] Weissmann C., Flechsig E., PrP knock-out and PrP transgenic mice in prion research, Br. Med. Bull. (2003) 66:43-60.

[87] Wells G.A., Konold T., Arnold M.E., Austin A.R., Hawkins S.A., Stack M., et al., Bovine spongiform encephalopathy: the effect of oral exposure dose on attack rate and incubation period in cattle, J. Gen. Virol. (2007) 88:1363-1373.

[88] Westaway D., DeArmond S.J., Cayetano-Canlas J., Groth D., Foster D., Yang S.L., et al., Degeneration of skeletal muscle, peripheral nerves, and the central nervous system in transgenic mice overexpressing wild- type prion proteins, Cell (1994) 76:117-129.

[89] Windl O., Buchholz M., Neubauer A., SchulzSchaeffer W., Groschup M., Walter S., et al., Breaking an absolute species barrier: transgenic mice expressing the mink $\operatorname{Pr} P$ gene are susceptible to transmissible mink encephalopathy, J. Virol. (2005) 79:1497114975.

[90] Zlotnik I., Stamp J.T., Scrapie in a Dorset Down ram. A confirmation of the histological diagnosis by means of intracerebral inoculation of mice with formol fixed brain tissue, Vet. Rec. (1965) 77:1178-1179. 